\title{
THE SYNTHESIS AND ELIMINATION OF HIPPURIC ACID IN NEPHRITIS: A NEW RENAL FUNCTION TEST *

\author{
PRELIMINARY PAPER
}

F. B. KINGSBURY, Ph.D. AND W. W. SWANSON, B.S.

\section{MINNEAPOLIS}

Since the time when Bunge and Schmiedeberg ${ }^{1}$ showed that the perfused dog kidney could effect the synthesis of hippuric acid from benzoic acid and glycine, it has been assumed by investigators, from time to time, that the synthetic ability of the kidney for the formation of hippuric acid could be used as an index of renal function. Rowntree and Geraghty, ${ }^{2}$ in their paper on the use of phenolsulphonephthalein as a means of testing renal function, enumerate among other renal tests that of the synthesis of hippuric acid. More recently, Violle ${ }^{3}$ reported that in nephritis the formation of hippuric acid is much less than in normal individuals after giving $0.5 \mathrm{gm}$. doses of sodium benzoate and collecting the twenty-four hour specimens. He found that in some cases the amount of extra hippuric acid corresponding to the amount of ingested benzoate was not excreted under forty-eight hours. The work of Kingsbury and Bell ${ }^{*}$ has thrown doubt on the view that the kidney is the only place in which hippuric acid is synthesized in the dog, and Friedmann and Tachau ${ }^{5}$ have proved that in the rabbit the perfused surviving liver can effect the synthesis of hippuric acid. Lackner, Levinson and Morse ${ }^{6}$ studied the effect of poisoning dogs with hydrazine sulphate on the synthesis of hippuric acid, and found

* From the Biochemical Laboratory of the Department of Physiology, University of Minnesota.

* A preliminary report was made in Chicago, December, 1920, before the Federation of American Societies for Experimental Biology.

1. Bunge, G., and Schmiedeberg, O.: Ueber die Bildung der Hippursaeure, Arch. exper. Path. u. Pharmakol. 6:233, 1876.

2. Rowntree, L. G., and Geraghty, T. J.: An Experimental and Clinical Study of the Functional Activity of the Kidneys by Means of Phenolsulphonephthalein, J. Pharmacol. \& Exper. Therap. 1:579, 1910.

3. Violle, P. L., Ann. de méd. 7:272, 1920; Abst. J. A. M. A. 75:435, 1920; Lancet 1:884, 1920 .

4. Kingsbury, F. B., and Bell, E. T.: The Synthesis of Hippuric Acid in Nephrectomized Dogs, J. Biol. Chem. 21:297 (June) 1915.

5. Friedmann, E., and Tachau, H.: Ueber die Bildung des Glykokolls im Tierkoerper, 1. Mitteilung; Synthese der Hippursaure in der Kanninchenleber, Biochem. Ztschr. 35:88, 1911.

6. Lackner, E., Levinson, A., and Morse, W.: The Rôle of the Liver in Hippuric Acid Synthesis, Biochem. J. 12:184, 1918. 
that with the liver extensively damaged, as it is by this poison, the synthesis of hippuric acid was greatly diminished. No damage to the kidney after use of hydrazine sulphate was demonstrated.

Jaarsveld and Stokvis, ${ }^{\top}$ using a slightly modified Bunge and Schmiedeberg method of analysis for the determination of benzoic and hippuric acids, estimated the amounts of these substances in the twentyfour hour urine of hospital patients suffering from various forms and degrees of nephritis after giving doses of sodium benzoate ranging from 0.3 to $4.5 \mathrm{gm}$. As controls, normal individuals were given amounts of sodium benzoate ranging from 0.4 to $2.0 \mathrm{gm}$. In four experiments with the controls these authors found no free, or unconjugated, benzoic acid excreted, but in the pathologic cases the percen-

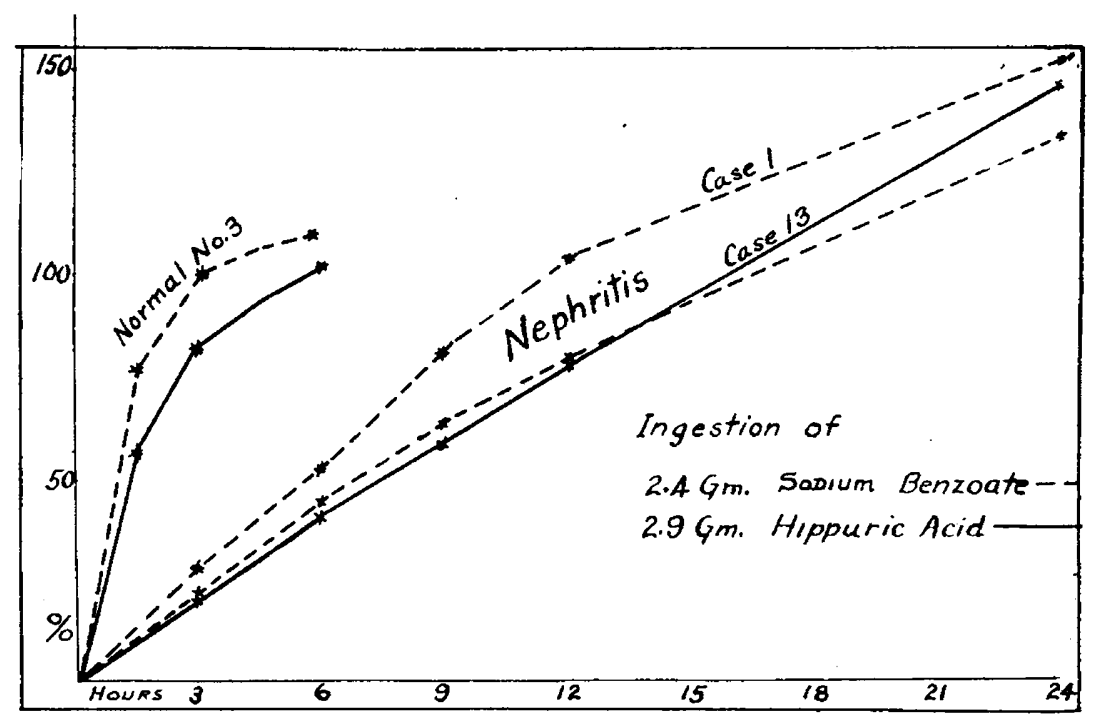

tage free of the total benzoic acid excreted varied from zero per cent. in the contracted kidney type of nephritis to as high as 100 per cent. in the chronic and actute parenchymatous type; in other words, no synthesis at all. They concluded that an extensive damage to the kidney parenchyma resulted in a lessened ability of this organ to function in synthesizing hippuric acid. They also found that the hippuric acid excretion was apparently related to the excretion of albumin, for in those urines containing much albumin smaller quantities of hippuric acid were always found than in urines free from albumin.

7. Jaarsveld, G. J., and Stokvis, B. J.: Ueber den Einfluss von Nierenaffectionen auf die Bildung von Hippursaeure, Arch. exper. Path. u. Pharmakol. 10:268, 1879 . 
Weyl and Anrep ${ }^{8}$ showed that in cases of pulmonary tuberculosis, ileotyphus and myelitis decubitus the normal twenty-four hour excretion of hippuric acid varied from 0.011 to $0.083 \mathrm{gm}$. , and that unconjugated benzoic acid was always present. In the only case in which this was estimated it amounted to $0.23 \mathrm{gm}$. as compared with $0.06 \mathrm{gm}$. hippuric acid found in the same urine. These authors used Bunge and Schmiedeberg's procedure.

Kronecker ${ }^{9}$ gave nephritics $0.5 \mathrm{gm}$. doses of sodium benzoate and found that in one case of contracted kidney, 74 per cent. of the total benzoic acid excreted in twenty-four hours was in the form of free benzoic acid and 26 per cent. was combined. In a second trial with the same patient a few days later, under exactly similar conditions of experiment, he found that the relations between free and combined benzoic acids were practically the reverse from those of the first experiment.

It will be seen from these brief summaries of previous work on the synthesis of hippuric acid in nephritis and other pathologic conditions that no agreement exists and this is easily explained as being due entirely to the analytical methods used. These were in every case either Bunge and Schmiedelerg's or some slight modification of it. In any case, the specimens of urine, if not already alkaline, were made so with sodium carbonate, and evaporated to dryness prior to the extraction and weighing of the hipptric and benzoic acids. It has been shown, and repeatedly referred to by various investigators, that hippuric acid is hydrolyzed by alkali. The large amounts of free benzoic acid were found in the urines which we can suppose were the ones most alkaline or which had been subjected to longer treatment with alkali, for the results which are to follow show that in nephritis hippuric acid is synthesized completely and, as far as can be learned, at practically the same rate as in normal individuals. Free benzoic acid, at least only in traces sufficient to require from 0.1 to 0.2 c.c. of tenth normal sodium ethylate for every 100 c.c. urine used, is all that can ever be obtained from pathologic or normal urine, provided that steps are taken to avoid any accidental hydrolysis of the hippuric acid present.

In the present paper we have based our test for renal function not on the supposed function of the kidney to form hippuric acid, but on its ability to excrete it. We have studied the rate of hippuric acid elimination after equivalent doses of benzoic or hippuric acids over short as well as over long periods with normal and pathologic individuals by methods of analysis not open to the criticism referred to above.

8. Weyl, Th., and Anrep, B.: Ueber die Ausscheidung der Hippursaenre und Benzoësaeure waehrend des Fiebers, Ztschr. Physiol. Chem. 4:169, 1880.

9. Kronecker, F.: Ueber die Hippursaeurebildung beim Menschen in Krankheiten, Arch, exper. Path. u. Pharmakol. 16:344, 1883. 


\section{ANALYTICAL METHODS}

Hippuric acid in the urines of our controls was analyzed by the Folin-Flanders' ${ }^{10}$ method directly, with one modification, which will be mentioned in its place. It was necessary to devise a way to remove albumin from urine before this method of analysis could be used in the cases of those urines containing it, since it has been known for a very considerable number of years, that by proper exidation of protein benzoic acid can be obtained. Kingsbury and Bell is showed that egg albumin, when subjected to the Folin-Flanders procedure, yielded titrable acid, some of which was benzoic acid. We have confirmed this finding and give below the number of cubic centimeters of one-tenth normal ethylate equivalent to various amounts of egg albumin. This substance dissolved in 100 c.c. water was put through this method.

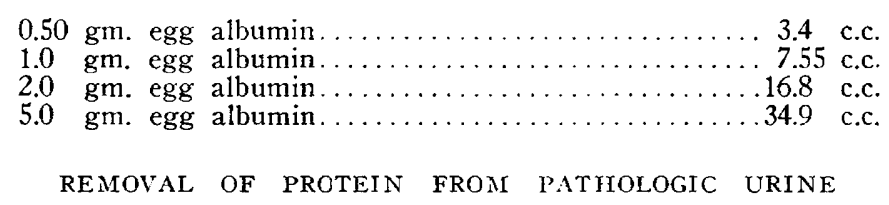

One hundred c.c. albuminous urine in a casserole are treated with 4 drops of 0.1 per cent. alcoholic solution of methyl red. This gives an acid reaction since our pathologic specimens are always collected in sufficient 2 per cent. nitric acid more than to neutralize the alkali present in such specimens ( 15 c.c. have been found adequate for a three hour specimen). Raiziss and Dubin ${ }^{12}$ have shown that there is no appreciable hydrolysis of hippuric acid in rabbit urine collected in an excess of 2 per cent. nitric acid. Sufficient normal sodium hydroxid is added, a drop at a time, to bring the color to the first definite yellow. The urine is now boiled to coagulate the protein, and during the boiling hydrochloric acid, approximately one-tenth normal, is added until a definite red coloration is noticed. Good coagulations are always obtained. This is the case whether the urine is at the first definite yellow of methyl red or at the first definite red, i.e. over a $\mathrm{Ph}$ range of from 5 to 6 , approximately. The clear filtrate is filtered off, the precipitate of protein washed with two 100 c.c. portions of boiling distilled water, and the combined filtrates and wash waters evaporated to dryness after adding 10 c.c. of 5 per cent. sodium hydroxid solution as in the regular procedure. The remainder of the method is exactly

10. Folin, O., and Flanders, F. F.: A New Method for the Determination of Hippuric Acid in Urine, J. Biol. Chem. 11:257 (April) 1912.

11. Kingsbury, F. B., and Bell, E. T.: The Synthesis of Hippuric Acid in Experimental Nephritis in the Rabbit, J. Biol. Chem. 20:73 (Jan.) 1915.

12. Raiziss, G. W., and Dubin, H.: On the Estimation of Benzoic Acid in the Urine, J. Biol. Chem. 20:125 (Feb.) 1915. 
that of Folin and Flanders, except the final stage referred to below. We have found that more consistent results, with better end points in the final titration of the resulting benzoic acid by the Folin-Flanders method, are obtained if the extract, instead of being drawn directly into a flask and titrated, is filtered through a dry filter paper, the 25 c.c. of neutral chloroform which is used to rinse the filter paper through which the extract has been passed also being used to rinse the separatory funnel from which the extract was drawn. The rinse chloroform is filtered through a second dry filter paper. This procedure removes all visible water. The only criticism which we have to make of the Folin-Flanders method is the length of time necessary for a determination, an allkali treatment of from two and one-half to four hours, an acid treatment of four and one-half hours and an extraction of from one-half to three-quarters of an hour longer. It seemed probable to us that a method could be devised which would take much less time without sacrificing any of the accuracy which is characterized by the Folin-Flanders method. We have done this, but we have not as yet given our method a sufficiently long trial to publish it. This we hope to do in the near future in The Journal of Biological Chemistry.

The method used for the determination of uncombined or free benzoic acid is that described by Raiziss and Dubin. ${ }^{12}$ Dakin, ${ }^{13}$ Lewis, ${ }^{14}$ Raiziss and Dubin ${ }^{1.5}$ and others have shown that in man benzoic acid is entirely converted into hippuric acid and excreted in this form. In pathologic cases our only information, as previously referred to, is a disagreement as to the excretion of benzoic acid or its salts. We have made the free benzoic acid determination in our pathologic cases a sufficient number of times, but have never found a titration figure in terms of c.c. of one-tenth normal sodium ethylate larger than that found for the same amount of normal urine, namely a blank of from 0.10 to 0.20 c.c. for 100 c.c. urine. Hippuric acid is the only form in which the total benzoic acid is excreted, in types of disease at least with which we have worked. As in the hippuric acid determination, protein. if present in the urine, must be removed before the acidified urine can be extracted with toluol in making the determination for free benzoic acid. Our method for this is as follows:

A 100 c.c. sample of albuminous urine in a 200 c.c. volumetric flask containing four drops of 0.10 per cent. methyl red solution is brought

13. Dakin, 1. D.: The Fate of Sodium Benzoate in the Human Organism, J. Biol. Chem. 7:103 (Jan.) 1910.

14. Lewis, H. B.: The Synthesis and Rate of Elimination of Hippuric Acid After Benzoate Ingestion in Man, J. Biol. Chem. 18:225 (July) 1914.

15. Raiziss, G. W., and Dubin, H.: The Synthesis of Hippuric Acid in the Animal Organism and the Occurrence of Free Benzoic Acid in the Urine, J. Biol. Chem. 21:331 ( July) 1915. 
to the first definite yellow by the addition of normal sodium hydroxid, then back to the first definite red by approximately one-tenth normal hydrochloric acid. Then, $0.5 \mathrm{gm}$. of tannic acid in substance is added. After complete solution of this substance and the consequent precipitation of the protein, the liquid is made up to volume, filtered through a dry filter paper and a 100 c.c. aliquot analyzed according to the method of Raiziss and Dubin. ${ }^{12}$

The simple coagulation method for the removal of protein prior to the application of the Folin-Flanders method gave consistent results in our hands. These are shown in Table 1 . The samples of urine, 100 c.c. each, contained from 0.5 to $1.0 \mathrm{gm}$. egg albumin (the dry product) and the values obtained were compared in each case with those of a similar quantity of the same sample of urine not containing egg albumin.

The results shown in Table 1 prove that albumin can be removed from urine according to the method outlined above without altering

table 1.-Data on Preliminary Removal of Protein

\begin{tabular}{|c|c|c|c|c|c|}
\hline \multicolumn{2}{|c|}{ Urine 1} & \multicolumn{2}{|c|}{ Urine 2} & \multicolumn{2}{|c|}{ Urine 3} \\
\hline $\begin{array}{c}\text { No Albumin } \\
\text { Present; } \\
\text { N/20 Sodium } \\
\text { Ethylate } \\
\text { Required, C.c. }\end{array}$ & $\begin{array}{c}\text { 1.0 Gm. Albu- } \\
\text { min Present; } \\
\text { N/20 Sodium } \\
\text { Ethylate } \\
\text { Required, C.c. }\end{array}$ & $\begin{array}{c}\text { No Albumin } \\
\text { Present; } \\
\text { N/20 Sodium } \\
\text { Ethylate } \\
\text { Required, C.c. }\end{array}$ & $\begin{array}{c}\text { 1.0 Gm. Albu- } \\
\text { min Present: } \\
\text { N/20 Sodium } \\
\text { Ethylate } \\
\text { Required, C.c. }\end{array}$ & $\begin{array}{c}\text { No Albumin } \\
\text { Present; } \\
\text { N/20 Sodium } \\
\text { Ethylate } \\
\text { Required, C.c. }\end{array}$ & $\begin{array}{l}\text { 0.5 Gm. Albu- } \\
\text { min Present; } \\
\text { N/20 Sodium } \\
\text { Ethylate } \\
\text { Required, C.e. }\end{array}$ \\
\hline 9.15 & 9.26 & 10.87 & 10.48 & 8.79 & 8.82 \\
\hline $\begin{array}{c}\text { Average of } \\
2 \text { determina- } \\
\text { tions }\end{array}$ & $\begin{array}{c}\text { Average of } \\
8 \text { determina- } \\
\text { tions }\end{array}$ & $\begin{array}{c}\text { Average of } \\
4 \text { determina } \\
\text { tions }\end{array}$ & $\begin{array}{c}\text { Average of } \\
2 \text { determina- } \\
\text { tions }\end{array}$ & $\begin{array}{c}\text { Average of } \\
4 \text { determina- } \\
\text { tions }\end{array}$ & $\begin{array}{l}\text { Average of } \\
4 \text { determina- } \\
\text { tions }\end{array}$ \\
\hline
\end{tabular}

appreciably the true hippuric acid titration value. In practice, albumin was removed when the sample of urine gave a coagulable quantity, determined on a 5 c.c. test sample, using the same technic as that described above.

\section{EXPERIMENTAL}

Our basic dose of sodium benzoate or hippurate is the equivalent of $2.0 \mathrm{gm}$. benzoic acid. The few exceptions to this are noted in the proper place. Since Lewis ${ }^{14}$ had shown that the excretion of hippuric acid following the ingestion of from 6 to $10 \mathrm{gm}$. doses of sodium benzoate was very rapid, from 85 to 90 per cent. of the dose being eliminated in from five to six hours, it seemed to us that with a dose of 2 gm. the elimination would be more rapid, and this has been found to be the case. We have found that the elimination of hippuric acid after the ingestion of $2.4 \mathrm{gm}$. sodium benzoate is 96 per cent. of the benzoate ingested for a 2.4 to 3.25 hour period. Directly determined and indirectly estimated, from the curves of excretion, the average for three hours for nine normal individuals is 97 per cent. 
In all cases, the sodium benzoate was dissolved in from 75 to 100 c.c. of water. This dose was taken and followed by half a glass of water used to rinse the container and glass from which the solution was taken. The benzoate was usually given between meals, either morning or afternoon, but in some cases one hour before breakfast, or with the meals. No difference could be noted either in the normal or pathologic cases due to the time of giving the sodium benzoate, with the exception of Case 12 Table 4, but we prefer the mid-morning or afternoon for this purpose. In every case care was taken to have the subject void urine immediately before taking the sodium benzoate. The diet was controlled only in so far as fruit in any form or cranberries were concerned. These were not allowed on the experiment day. The amount of water taken during the experiment period was not controlled in the normal cases, nor could any differences in the results, possibly due to this, be noticed. The water intake was controlled in the pathologic cases.

In those experiments in which hippuric acid was given this was dissolved at room temperature by the aid of sodium bicarbonate, avoiding an excess of the latter. The hippuric acid used in these experiments was for the most part synthesized from benzoyl chlorid and glycine in slightly alkaline solution, entirely freed from benzoic acid and recrystallized two or three times from hot water and the crystals thoroughly dried. Some of it was purchased from the Eastman Kodak Company. ${ }^{16}$

Previous mention has been made of the fact that our pathologic specimens of urine were collected in 15 c.c. of 2.0 per cent. nitric acid for each three hour specimen to prevent hydrolysis of the hippuric acid, and it should be noted that when the specimen of urine had to stand over more than six or eight hours before the analysis of it could be undertaken, it was preserved by adding 0.5 c.c. of a 10 per cent. solution of thymol in chloroform. Such preservation makes no difference in the analytical results, as we have demonstrated several times.

The administration of salicylates, at least in any quantity, just before or during the experiment period should be avoided. Salicylates present in urines analyzed by the Folin-Flanders method yield results that are too high, due, probably, to the formation of picric acid or analogous substances which yield a certain titration value of their own. We have found that picric acid can be proved to be present when 1.0 gm. salicylic acid or acetylsalicylic acid is put through the FolinFlanders procedure. None of our normal or pathologic results were influenced in this way.

16. For this and certain other chemicals for research purposes acknowledgment is made to the Graduate School of the University of Minnesota. 
In general, we have found it advantageous to make the three hour pathologic specimens up to 500 c.c. and take 100 c.c. aliquots for analysis.

The average daily excretion of hippuric acid is given in text books on physiological chemistry as from 0.7 to $1.0 \mathrm{gm}$., but the more accurate figures of Folin and Flanders indicate that it varies from 0.8 to 1.9 gm. a day. This has been determined in the case of a normal man weighing approximately $90 \mathrm{~kg}$. and the results are shown in Table $2 .^{17}$

The results shown in Table 2 confirm the findings of others that the hippuric acid output is fairly constant for the individual on a constant diet, and that fruit and vegetables increase it. The average daily excretion in this case on the mixed diet is $1.70 \mathrm{gm}$. as hippuric acid, or a three-hourly excretion of $0.144 \mathrm{gm}$. calculated as benzoic acid. On

TABLE 2.-Normal Hippuric Acid Excretion

\begin{tabular}{|c|c|c|}
\hline $\begin{array}{c}\text { Date: } \\
\text { June, } 1919 \\
10 \\
11 \\
12 \\
13 \\
14 \\
16\end{array}$ & $\begin{array}{c}24 \text { Hour } \\
\text { Hippuric Acid, Gm. } \\
1.58 \\
1.85 \\
1.51 \\
1.61 \\
1.80 \\
1.85\end{array}$ & $\begin{array}{c}\text { Diet } \\
\text { Mixed, including a fair } \\
\text { amount of fruit }\end{array}$ \\
\hline $\begin{array}{l}17 \\
18 \\
19 \\
20 \\
21 \\
22 \\
23 \\
24\end{array}$ & $\begin{array}{l}1.60 \\
1.14 \\
0.85 \\
0.99 \\
0.87 \\
0.85 \\
0.90 \\
0.93\end{array}$ & $\begin{array}{l}\text { Milk, cheese, cream and rock candy, } \\
\text { but no fruit or vegetables }\end{array}$ \\
\hline
\end{tabular}

the low hippuric acid forming, but high protein diet (from 20 to $22 \mathrm{gm}$. total nitrogen in twenty-four hours) the output of hippuric acid, averaging the figures from June 19 to 24 , inclusive, is $0.90 \mathrm{gm}$. as hippuric acid, or a three-hourly excretion of $0.077 \mathrm{gm}$. calculated as benzoic acid.

We have disregarded the ordinary three hour excretion of hippuric acid in the normal and pathologic cases, and have simply determined the amount of hippuric acid excreted in this time after the ingestion of the equivalent of $2 \mathrm{gm}$. benzoic acid, expressing this in per cent. of the ingested substance. Our figures, then, include this ordinary output which is too small relatively to affect the results of our comparison of the rates of hippuric acid elimination in normal and pathologic subjects under these conditions. Directly determined, the twenty-four hour output of hippuric acid on a fruit free diet was in Case 19, $0.25 \mathrm{gm}$.,

17. Done by Mr. Wallace Cole in an elective course under the direction of F. B. Kingsbury. 
in Case 20, $1.08 \mathrm{gm}$., and in Case 21, $0.321 \mathrm{gm}$., all calculated as benzoic acid. The three-hourly output in each case calculated as benzoic acid was $0.03,0.14$ and 0.04 gram, respectively.

Violle ${ }^{3}$ recently brought forth a renal function test based on the supposed ability of the kidney to synthesize hippuric acid. He has found that a forty-eight hour period is sometimes necessary in cases of nephritis for the synthesis of hippuric acid equivalent to $0.5 \mathrm{gm}$. benzoic acid. Our findings, which were about half complete when the abstracts of Violle's paper were available, do not confirm those of Voille. The original article of Violle has not yet arrived, and we are, therefore, in ignorance as to more of the details of his work and particularly as to the analytical methods employed.

Case histories have been omitted from our paper, but all the clinical findings that could throw light on the results have been included. Results with the normal subjects are shown in Table 3, with pathologic subjects in Table 4.

\section{DISCUSSION OF RESULTS}

In summarizing our results, we have classified our patients into: (1) Nephritics; (2) cardiac decompensation with passive congestion of the kidneys, and (3) miscellaneous cases. In Table 5, dealing with well marked cases of nephritis, it is seen that a low phenolsulphonephthalein test is associated with a low benzoate test. With the exception of Cases 1 and 8, with extremely low phenolsulphonephthalein tests these values ranged from 10 to 20 per cent. for adults and were associated with benzoate tests of from 10 to 50 per cent. With twelve cardiac cases shown in Table 6 , the phenolsulphonephthalein percentages varied from 20 to 47 , the latter being the lower limit of what is regarded by some internists as normality, and are generally higher than with cases of nephritis. It is pointed out in this connection that the benzoate tests on these patients are generally relatively higher than the corresponding phenolsulphonephthalein tests; for instance, half of them by the former test ranging from 60 to 80 per cent., and half from 20 to 60 per cent., but none lower than 20 per cent. Generally, then, the benzoate test shows greater differences between these two types of cases than does the phenolsulphonephthalein test. In Table 4 it will be noted that in Cases 8 and 10 several benzoate tests were made, and that the values obtained fluctuated markedly. Apparently, this is due to the condition of the heart and its ability to maintain an adequate renal circulation during the time of the test. Fluctuations in the benzoate test when applied to the nephritic are by no means so marked. Case 13 showed steady clinical improvement from November 27 to December 8. During this period, the benzoate test percentages rose from 10 to 22 and the phenolsulphonephthalein values from 20 to 35 per cent. in two hours. 
TABLE 3.--Normal Individuals

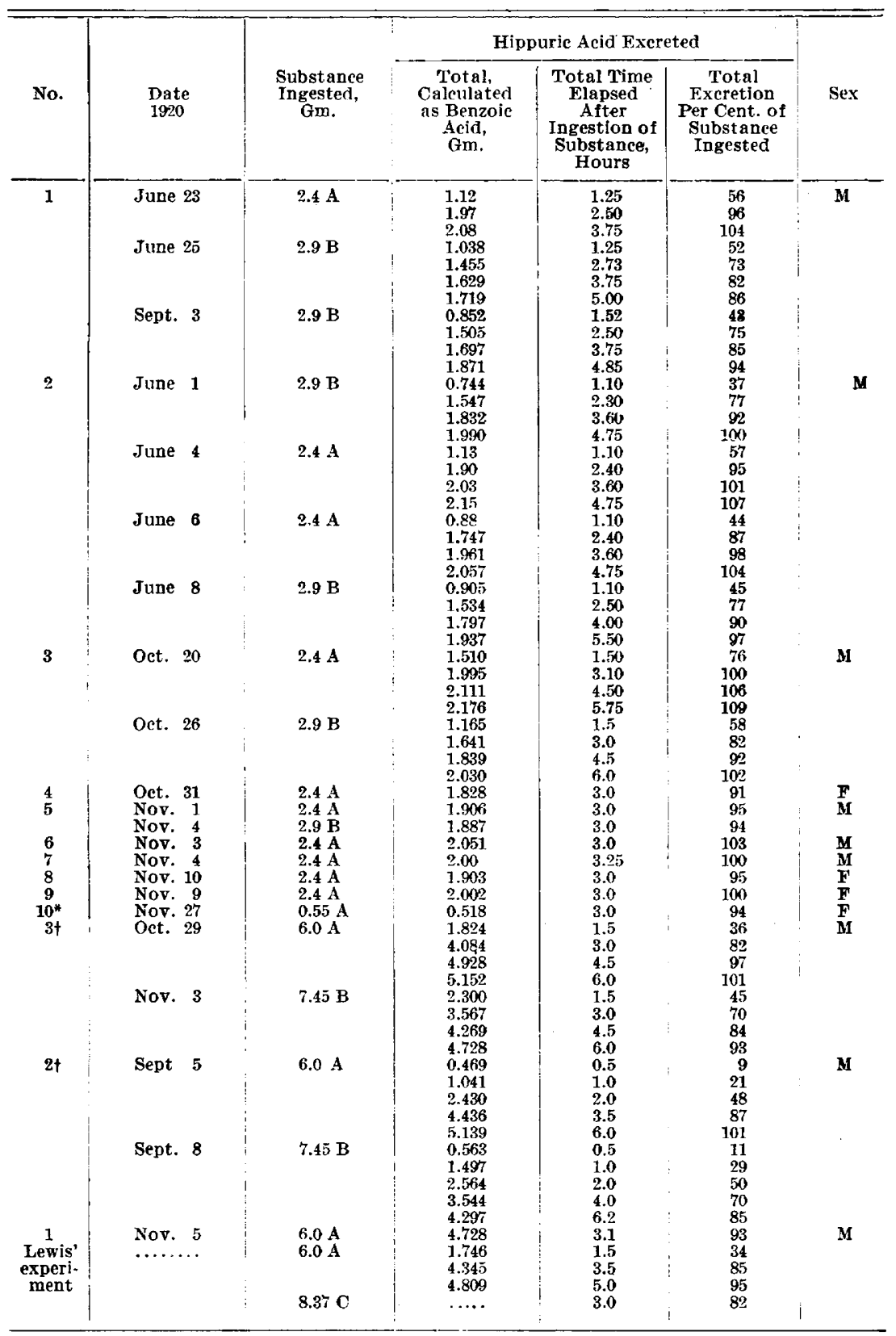

A, sodium benzoate; $B$, hippuric acid; $C$, solium hippurate.

* Child 2.5 years old.

t Repetition of Lewis' experiments. 
TABLE 4.-Pathologic Individuals

\begin{tabular}{|c|c|c|c|c|c|c|c|c|c|c|}
\hline \multirow[b]{2}{*}{ No. } & \multirow[b]{2}{*}{$\begin{array}{l}\text { Date, } \\
1920\end{array}$} & \multirow[b]{2}{*}{$\begin{array}{l}\text { Sub- } \\
\text { stance } \\
\text { In- } \\
\text { gested, } \\
\text { Gm. }\end{array}$} & \multicolumn{3}{|c|}{ Hippuric Acid Exereted } & \multirow[b]{2}{*}{$\begin{array}{l}\text { Albu- } \\
\text { min } \\
\text { in } \\
\text { Urine }\end{array}$} & \multirow[b]{2}{*}{$\begin{array}{l}\text { Phenol- } \\
\text { sul- } \\
\text { phone- } \\
\text { phthalein } \\
\text { Ex- } \\
\text { creted } \\
\text { in } \\
2 \text { Hours, } \\
\text { per Cent. }\end{array}$} & \multirow{2}{*}{\multicolumn{2}{|c|}{$\begin{array}{l}\text { Diagnosis and } \\
\text { Remarks }\end{array}$}} & \multirow[b]{2}{*}{ Sex } \\
\hline & & & $\begin{array}{c}\text { Total } \\
\text { Calcu- } \\
\text { lated } \\
\text { as } \\
\text { Benzoic } \\
\text { Acid, } \\
\text { Gm. }\end{array}$ & $\begin{array}{l}\text { Total } \\
\text { Time } \\
\text { Elapsed } \\
\text { After } \\
\text { Inges- } \\
\text { tion of } \\
\text { Sub- } \\
\text { stance, } \\
\text { Hours }\end{array}$ & \begin{tabular}{|c|} 
Total \\
Excre- \\
tion \\
per \\
Cent. \\
of \\
Sub- \\
stance \\
Ingested
\end{tabular} & & & & & \\
\hline $\mathbf{1}$ & $\begin{array}{l}\text { Mar. } 29 \\
\text { April } 3\end{array}$ & $\begin{array}{l}2.6 \mathrm{~B} \\
2.4 \mathrm{~A}\end{array}$ & $\begin{array}{l}0.432 \\
1.041 \\
0.557 \\
1.054 \\
1.618 \\
2.070 \\
3.034 \\
0.521 \\
0.965 \\
1.375 \\
1.610\end{array}$ & $\begin{array}{c}3 \\
6 \\
3 \\
6 \\
9 \\
12 \\
24 \\
3 \\
5.4 \\
8 \\
9.3\end{array}$ & $\begin{array}{r}24 \\
59 \\
28 \\
53 \\
81 \\
104 \\
152 \\
26 \\
48 \\
69 \\
81\end{array}$ & $\begin{array}{l}+ \\
+\end{array}$ & $\stackrel{1.5}{\text { April } 17}$ & $\begin{array}{c}\text { Chronic } \\
\text { nephritis }\end{array}$ & $\begin{array}{l}\text { Necropsy } \\
\text { May } 10\end{array}$ & $\mathbf{M}$ \\
\hline 2 & \begin{tabular}{l|} 
May 11 \\
May 13
\end{tabular} & $\begin{array}{l}2.4 \mathrm{~A} \\
2.9 \mathrm{~B}\end{array}$ & $\begin{array}{l}0.221 \\
0.857 \\
0.318 \\
0.982\end{array}$ & $\begin{array}{l}3 \\
57 \\
3 \\
6\end{array}$ & $\begin{array}{l}11 \\
43 \\
16 \\
50\end{array}$ & $\begin{array}{l}+ \\
+\end{array}$ & $\begin{array}{c}29 \\
\text { April } 4 \\
31 \\
\text { June } 6\end{array}$ & $\begin{array}{c}\text { Chronic } \\
\text { nephritis; } \\
\text { cardiac } \\
\text { decom- } \\
\text { pensation }\end{array}$ & $\ldots \ldots \ldots$ & $\mathbf{M}$ \\
\hline $\mathbf{3}$ & May 4 & $2.4 \mathrm{~A}$ & $\begin{array}{l}0.514 \\
1.016\end{array}$ & $\begin{array}{l}3 \\
6\end{array}$ & $\begin{array}{l}26 \\
51\end{array}$ & $\cdots$ & $\cdots \cdots$ & $\begin{array}{c}\text { Cardiac } \\
\text { decom- } \\
\text { pensation }\end{array}$ & $\ldots \ldots \ldots$ & $\mathbf{M}$ \\
\hline 4 & $\begin{array}{l}\text { Sept. } 3 \\
\text { Sept. } 10\end{array}$ & $\begin{array}{l}2.4 \mathrm{~A} \\
2.9 \mathrm{~B}\end{array}$ & $\begin{array}{l}0.542 \\
1.073 \\
0.304 \\
0.415\end{array}$ & $\begin{array}{l}3 \\
6 \\
2.6 \\
6\end{array}$ & $\begin{array}{l}27 \\
54 \\
15 \\
21\end{array}$ & . & $\begin{array}{l}28 \\
\text { Sept. } 8\end{array}$ & $\begin{array}{l}\text { Aortitis } \\
\text { syphilis; } \\
\text { cardiac } \\
\text { hyper- } \\
\text { trophy }\end{array}$ & $\begin{array}{c}\text { Necropsy } \\
\text { Sept. } 11\end{array}$ & $\mathbf{M}$ \\
\hline 5 & Sept. 3 & $2.4 \mathrm{~A}$ & $\begin{array}{l}0.866 \\
1.390\end{array}$ & $\begin{array}{l}3 \\
6\end{array}$ & $\begin{array}{l}43 \\
69\end{array}$ & + & $\stackrel{25}{\text { Aug. } 16}$ & $\begin{array}{c}\text { Cardiac } \\
\text { decom- } \\
\text { pensation }\end{array}$ & $\ldots \ldots \ldots$ & $\mathbf{F}$ \\
\hline 6 & $\begin{array}{l}\text { Oct. } 11 \\
\text { Oct. } 13 \\
\text { Nov. } 16\end{array}$ & $\begin{array}{l}2.4 \mathrm{~A} \\
2.9 \mathrm{~B} \\
2.4 \mathrm{~A}\end{array}$ & $\begin{array}{l}1.324 \\
0.949 \\
1.270\end{array}$ & $\begin{array}{l}3 \\
3 \\
4.5\end{array}$ & $\begin{array}{l}66 \\
48 \\
64\end{array}$ & . & $\begin{array}{l}50 \\
\text { Oct. } 9\end{array}$ & $\begin{array}{c}\text { Cirrhosis; } \\
\text { cardiac } \\
\text { decom- } \\
\text { pensation }\end{array}$ & $\begin{array}{l}\text { Necropsy } \\
\text { Nov. } 21\end{array}$ & $\mathbf{M}$ \\
\hline 7 & Sept. 30 & $2.4 \mathrm{~A}$ & $\begin{array}{l}1.314 \\
2.055\end{array}$ & $\begin{array}{l}3 \\
6\end{array}$ & $\begin{array}{r}66 \\
103\end{array}$ & . & $\stackrel{40}{\text { Sept. } 9}$ & $\begin{array}{c}\text { Mitral } \\
\text { stenosis }\end{array}$ & $\ldots \ldots \ldots$ & $\mathbf{M}$ \\
\hline 8 & $\begin{array}{l}\text { Nov. } 13 \\
\text { Nov. } 16 \\
\text { Nov. } 23 \\
\text { Nov. } 27\end{array}$ & $\begin{array}{l}2.4 \mathrm{~A} \\
2.4 \mathrm{~A} \\
2.4 \mathrm{~A} \\
2.4 \mathrm{~A}\end{array}$ & $\begin{array}{l}0.706 \\
1.259 \\
1.797 \\
0.964\end{array}$ & $\begin{array}{l}3 \\
3.9 \\
3 \\
3\end{array}$ & $\begin{array}{r}35 \\
63 \\
90 \\
.48\end{array}$ & + & $\begin{array}{l}43 \\
\text { Nov. } 11\end{array}$ & $\begin{array}{c}\text { Cardiac } \\
\text { decom- } \\
\text { pensation }\end{array}$ & $\ldots \ldots \ldots$ & $\mathbf{M}$ \\
\hline 9 & $\begin{array}{l}\text { Nov. } 13 \\
\text { Nov. } 16\end{array}$ & $\begin{array}{l}2.4 \mathrm{~A} \\
2.4 \mathrm{~A}\end{array}$ & $\begin{array}{l}1.235 \\
1.260\end{array}$ & $\begin{array}{l}3 \\
3\end{array}$ & $\begin{array}{l}62 \\
63\end{array}$ & . & $\begin{array}{c}43 \\
\text { Nov. } 12\end{array}$ & $\begin{array}{l}\text { Angina } \\
\text { pectoris }\end{array}$ & $\ldots \ldots \ldots$ & $\mathbf{M}$ \\
\hline 10 & $\begin{array}{l}\text { Nov. } 16 \\
\text { Nov. } 20 \\
\text { Nov. } 27\end{array}$ & $\begin{array}{l}2.4 \mathrm{~A} \\
2.4 \mathrm{~A} \\
2.4 \mathrm{~A}\end{array}$ & $\begin{array}{l}1.203 \\
0.691 \\
1.176\end{array}$ & $\begin{array}{l}3 \\
3 \\
3\end{array}$ & $\begin{array}{l}60 \\
35 \\
59\end{array}$ & $\cdots$ & 45 & $\begin{array}{c}\text { Cardiac } \\
\text { valvular } \\
\text { disease }\end{array}$ & .. & $\mathbf{M}$ \\
\hline 11 & $\begin{array}{l}\text { Nov. } 13 \\
\text { Nov. } 16 \\
\text { Nov. } 23 \\
\text { Nov. } 27\end{array}$ & $\begin{array}{l}2.4 \mathrm{~A} \\
2.4 \mathrm{~A} \\
2.4 \mathrm{~A} \\
2.4 \mathrm{~A}\end{array}$ & $\begin{array}{l}1.075 \\
1.623 \\
1.601 \\
1.682\end{array}$ & $\begin{array}{l}3.3 \\
3 \\
3 \\
3\end{array}$ & $\begin{array}{l}54 \\
81 \\
80 \\
84\end{array}$ & . & $\ldots \ldots$ & $\begin{array}{c}\text { Mitral } \\
\text { stenosis }\end{array}$ & ......... & $\mathbf{F}$ \\
\hline 12 & $\begin{array}{l}\text { Nov. } 13 \\
\text { Nov. } 16\end{array}$ & $\begin{array}{l}1.2 \mathrm{~A}^{*} \\
1.2 \mathrm{At}\end{array}$ & $\begin{array}{l}0.955 \\
0.683\end{array}$ & $\begin{array}{l}3 \\
3\end{array}$ & $\begin{array}{l}96 \\
68\end{array}$ & . & $\ldots \ldots \ldots$ & $\begin{array}{l}\text { Gastric } \\
\text { ulcer }\end{array}$ & $\ldots \ldots \ldots$ & $\mathbf{M}$ \\
\hline 13 & $\begin{array}{lr}\text { Nov. } & 27 \\
\text { Dec. } & 3 \\
\text { Dec. } & 8\end{array}$ & $\begin{array}{l}2.4 \mathrm{~A} \\
2.4 \mathrm{~A} \\
2.4 \mathrm{~A}\end{array}$ & $\begin{array}{l}0.193 \\
0.349 \\
0.438 \\
0.891 \\
1.281 \\
1.582 \\
2.667 \\
0.396 \\
0.812 \\
1.186 \\
1.559 \\
2.916\end{array}$ & $\begin{array}{r}3 \\
3 \\
3 \\
6 \\
9 \\
12 \\
24 \\
3 \\
6 \\
9 \\
12 \\
24\end{array}$ & $\begin{array}{r}10 \\
17 \\
22 \\
45 \\
64 \\
79 \\
133 \\
20 \\
41 \\
59 \\
78 \\
146\end{array}$ & + & $\stackrel{17}{\text { Nov. } 25}$ & $\begin{array}{c}\text { Chronic } \\
\text { nephritis }\end{array}$ & $\begin{array}{l}\text { Clinical } \\
\text { improve- } \\
\text { ment }\end{array}$ & $\mathbf{M}$ \\
\hline
\end{tabular}


TABLE 4.-PATHologic Individuals-(Continued)

\begin{tabular}{|c|c|c|c|c|c|c|c|c|c|c|}
\hline \multirow[b]{2}{*}{ No. } & \multirow[b]{2}{*}{$\begin{array}{l}\text { Date, } \\
1920\end{array}$} & \multirow[b]{2}{*}{$\begin{array}{l}\text { Sub- } \\
\text { stance } \\
\text { In- } \\
\text { gested, } \\
\text { Gm. }\end{array}$} & \multicolumn{3}{|c|}{ Hippuric Acid Exereted } & \multirow[b]{2}{*}{$\begin{array}{l}\text { Albu- } \\
\text { min } \\
\text { in } \\
\text { Urine }\end{array}$} & \multirow{2}{*}{\begin{tabular}{|c|} 
Phenol- \\
sul- \\
phone- \\
phthalein \\
Ex- \\
creted \\
in \\
2 Hours, \\
per Cent.
\end{tabular}} & \multirow{2}{*}{\multicolumn{2}{|c|}{$\begin{array}{c}\text { Diagnosis and } \\
\text { Remarks }\end{array}$}} & \multirow[b]{2}{*}{ Sex } \\
\hline & & & $\begin{array}{c}\text { Total } \\
\text { Calcu- } \\
\text { lated } \\
\text { as } \\
\text { Benzoic } \\
\text { Acid, } \\
\text { Gm. }\end{array}$ & $\begin{array}{c}\text { Total } \\
\text { Time } \\
\text { Elapsed } \\
\text { After } \\
\text { Inges- } \\
\text { tion of } \\
\text { Sub- } \\
\text { stance, } \\
\text { Hours }\end{array}$ & \begin{tabular}{|} 
Total \\
Excre- \\
tion \\
per \\
cent. \\
of \\
Sub- \\
stance \\
Ingested
\end{tabular} & & & & & \\
\hline 14 & $\begin{array}{lr}\text { Dec. } & 3 \\
\text { Dec. } & 7 \\
\text { Dec. } & 10\end{array}$ & $\begin{array}{l}2.4 \mathrm{~A} \\
2.4 \mathrm{~A} \\
2.4 \mathrm{~A}\end{array}$ & $\begin{array}{l}0.910 \\
1.395 \\
1.651\end{array}$ & $\begin{array}{l}3 \\
3 \\
3\end{array}$ & $\begin{array}{l}45 \\
70 \\
83\end{array}$ & . & $\begin{array}{c}20 \\
35 \\
\text { Dec. } 11\end{array}$ & $\begin{array}{c}\text { Cardiac } \\
\text { decom- } \\
\text { pensation }\end{array}$ & $\ldots \ldots \ldots$ & $\mathbf{M}$ \\
\hline 15 & Dec. 3 & $0.8 \mathrm{~A}$ & 0.469 & 3 & 69 & . & $\begin{array}{c}70 \\
\text { Dec. } 10\end{array}$ & $\begin{array}{l}\text { Postscarla- } \\
\text { tinal ne- } \\
\text { phritis in } \\
\text { stage of } \\
\text { recovery }\end{array}$ & $\begin{array}{c}\text { Child Il } \\
\text { years }\end{array}$ & $\mathbf{M}$ \\
\hline 16 & Dec. 7 & $2.4 \mathrm{~A}$ & 0.568 & 3 & 28 & + & $\begin{array}{c}10 \\
\text { Dec. } 6\end{array}$ & Nephritis & $\ldots \ldots \ldots$ & $M$ \\
\hline 17 & Dec. 10 & $2.4 \mathrm{~A}$ & 0.812 & 3 & 41 & .. & $\cdots$ & $\begin{array}{c}\text { Pyloric } \\
\text { obstruc- } \\
\text { tion }\end{array}$ & $\ldots \ldots \ldots$ & $\mathbf{M}$ \\
\hline 18 & $\begin{array}{c}1921 \\
\text { Jan. } 10\end{array}$ & $2.4 \mathrm{~A}$ & $\begin{array}{l}1.630 \\
3.040\end{array}$ & $\begin{array}{r}3 \\
24\end{array}$ & $\begin{array}{r}82 \\
152\end{array}$ & + & $\begin{array}{l}35 \\
45\end{array}$ & $\begin{array}{c}\text { Nephrosis } \\
\text { due to } \\
\text { abscess }\end{array}$ & 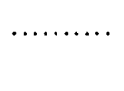 & $\mathbf{F}$ \\
\hline 10 & Jan. 9 & $2.4 \mathrm{~A}$ & $\begin{array}{l}1.410 \\
2.544\end{array}$ & $\begin{array}{r}3 \\
24\end{array}$ & $\begin{array}{r}71 \\
127\end{array}$ & .. & 52 & $\begin{array}{l}\text { Pyelocys- } \\
\text { titis }\end{array}$ & $\ldots \ldots \ldots$ & $\mathbf{F}$ \\
\hline 20 & Jan. 9 & $2.4 \mathrm{~A}$ & 1.342 & 3 & 67 & .. & 47 & $\begin{array}{c}\text { Cardiac } \\
\text { decom- } \\
\text { pensation }\end{array}$ & $\cdots \cdots$ & $\mathbf{F}$ \\
\hline 21 & Jan. 9 & $2.4 \mathrm{~A}$ & $\begin{array}{l}1.925 \\
2.542\end{array}$ & $\begin{array}{r}3 \\
24\end{array}$ & $\begin{array}{r}96 \\
127\end{array}$ & . & 43 & $\begin{array}{l}\text { Arterio- } \\
\text { selerosis }\end{array}$ & $\ldots \ldots \ldots$ & $F$ \\
\hline 22 & Jan. 10 & $2.4 \mathrm{~A}$ & 1.980 & 3 & 99 & . & $\ldots \ldots$ & $\begin{array}{l}\text { Diabetes } \\
\text { mellitus }\end{array}$ & $\ldots \ldots \ldots$ & $\mathbf{M}$ \\
\hline 23 & $\begin{array}{l}\text { Jan. } 11 \\
\text { Jan. } 15\end{array}$ & $\begin{array}{l}2.4 \mathrm{~A} \\
2.4 \mathrm{~A}\end{array}$ & $\begin{array}{l}0.806 \\
1.026\end{array}$ & $\begin{array}{l}\mathbf{3} \\
\mathbf{3}\end{array}$ & $\begin{array}{l}40 \\
51\end{array}$ & $\cdots$ & 20 & Nephritis & $\ldots \ldots \ldots$ & $\mathbf{M}$ \\
\hline 24 & Jan. 15 & $2.4 \mathrm{~A}$ & 1.419 & 3 & 71 & . & ......... & $\begin{array}{c}\text { Cardiac } \\
\text { decom- } \\
\text { pensation }\end{array}$ & & M \\
\hline 25 & Jan. 15 & $2.4 \mathrm{~A}$ & 0.815 & 3 & 41 & . & $\ldots \ldots$ & $\begin{array}{l}\text { Brady- } \\
\text { cardia }\end{array}$ & & $\mathbf{M}$ \\
\hline 26 & Jan. 15 & $2.4 \mathrm{~A}$ & 1.852 & 3 & 93 & . & 62 & Asthma & & \\
\hline 27 & $\begin{array}{l}\text { Jan. } 16 \\
\text { Jan. } 18\end{array}$ & $\begin{array}{l}1.06 \mathrm{C} \\
1.25 \mathrm{~A}\end{array}$ & $\begin{array}{l}0.479 \\
0.994\end{array}$ & $\begin{array}{l}3 \\
3\end{array}$ & $\begin{array}{l}45 \\
94\end{array}$ & .. & $\cdots$ & $\begin{array}{l}\text { Nephritis, } \\
\text { chronic } \\
\text { interstitial }\end{array}$ & $\begin{array}{l}\text { Child } 11 \\
\text { years } \\
\text { old }\end{array}$ & $\mathbf{F}$ \\
\hline 28 & Jan. 21 & $2.4 \mathrm{~A}$ & 0.938 & 3 & 47 & + & $\ldots \ldots \ldots$ & Nephritis & $\ldots \ldots \ldots$ & $\mathbf{M}$ \\
\hline
\end{tabular}

A, sodium benzoate; $\mathbf{B}$, hippuric acid; $\mathrm{C}$, benzoic acid.

* Benzoate ingested 1 hour before breakfast.

* Benzoate ingested with noon meal.

† See text. 
Whether the benzoate test can be used as a means of differential diagnosis between the cases primarily cardiac and those primarily renal, our data are at present insufficient to decide, but the results presented in this paper indicate that this is a possibility, and that if several tests are made on the same patient two or three days apart, that with carefully controlled conditions of diet there would be very marked fluctuations in the values obtained with the cases primarily cardiac, but with the nephritics a greater constancy (Cases 1, 8, 10 and 13, Table 4).

Certain advantages which the benzoate test appears to have in comparison with the phenolsulphonephthalein test are: (1) Normal values within narrow limits; (2) greater delicacy in picturing kidney function; (3) simplicity in making the test, and (4) excretion of a substance normally eliminated by the kidney.

The normal values as we have found them for adults vary from 95 to 100 per cent. elimination in three hours. These were made on

TABLE 5.-Nephritis; Benzoate: Tests

\begin{tabular}{|c|c|c|c|c|c|c|}
\hline \multirow{2}{*}{$\begin{array}{l}\text { Adults............... } \\
\text { Children............ }\end{array}$} & \multirow{2}{*}{$\begin{array}{c}\text { Phenolsul- } \\
\text { phonephthalein } \\
\text { Per Cent. } \\
1.5-30 \\
53-70\end{array}$} & \multicolumn{5}{|c|}{ Number of Cases Between } \\
\hline & & $\begin{array}{c}10-20 \% \\
2 \\
0\end{array}$ & $\begin{array}{c}20-30 \% \\
2 \\
0\end{array}$ & $\begin{array}{c}30-40 \% \\
0 \\
0\end{array}$ & $\begin{array}{c}40-50 \% \\
2 \\
0\end{array}$ & $\begin{array}{c}50-100 \% \\
0 \\
2\end{array}$ \\
\hline
\end{tabular}

TABle 6.-Cardiac Casies; Benzoate Tests

\begin{tabular}{|c|c|c|c|c|c|c|}
\hline \multirow[b]{2}{*}{ 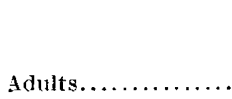 } & \multirow{2}{*}{$\begin{array}{c}\text { Phenolsul- } \\
\text { phonephthalein } \\
\text { Per Cent. } \\
20-47\end{array}$} & \multicolumn{5}{|c|}{ Number of Cases Between } \\
\hline & & $\begin{array}{c}10-20 \% \\
0\end{array}$ & $\begin{array}{c}20-40 \% \\
2\end{array}$ & $\begin{array}{c}40-60 \% \\
4\end{array}$ & $\begin{array}{c}60-80 \% \\
6\end{array}$ & $\begin{array}{c}80-100 \% \\
0\end{array}$ \\
\hline
\end{tabular}

members of the faculty of the medical school and students. Only one normal result was as low as 91 per cent. At present, we have only one figure for the normal output of hippuric acid in three hours for children. This was obtained by giving a $2 \frac{1}{2}$ year old girl, weighing about 34 pounds, $0.55 \mathrm{gm}$. sodium benzoate or $34 / 150$ of 2.4 on the basis that the latter is the correct dosage for an adult weighing 150 pounds. The result obtained in this case was a 94 per cent. elimination in three hours. Fluctuations in the phenolsulphonephthalein values obtained on normal subjects are enormous. With adults 15 per cent. or more of the injected dye is not recovered, and its fate is unknown, but Kendall ${ }^{18}$ has given a clue to the manner in which this substance may be destroyed in the body. It has been our experience that patients object far less to taking a dose of sodium benzoate in solution than to having an intermuscular injection of phenolsulphonephthalein.

18. Kendall, E. C.: The Fate of Phenolsulphonephthalein When Injected Into the Animal Organism, J. A. M. A. 66:343 (Feb. 3) 1917. 
Of interest are the results of the benzoate test applied to two children (Cases 15 and 27, Table 4). Case 15, an 11 year old boy just recovering from a postscarlatinal nephritis, with a phenolsulphonephthalein test of 70 per cent. elimination in two hours, has a benzoate test of 69 per cent., indicating lowered renal efficiency. Case 27, an 11 year old girl, with a phenolsulphonephthalein test of 53 per cent. in two hours, has a benzoate test of 94 per cent. This case was diagnosed as chronic interstitial nephritis on the history of the case, the urinary findings and the blood pressure-systolic 170 and diastolic $130 \mathrm{~m} . \mathrm{m}$. of mercury, respectively. In this instance the Mosenthal ${ }^{19}$ renal test was applied and found to be nearly normal and more closely agreed with the benzoate test than with the phenolsulphonephthalein test. The value of the latter, 53 , is lower than the average figure of

Table 7.-Mischllaneous Cases; Benzoate Tests

\begin{tabular}{|c|c|c|c|}
\hline 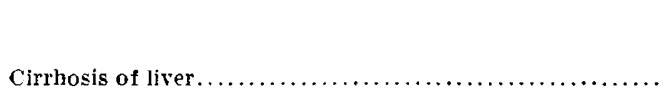 & $\begin{array}{c}\text { Number of } \\
\text { Cases } \\
2\end{array}$ & $\begin{array}{l}\text { Phenol- } \\
\text { sulphone- } \\
\text { phthalein } \\
50 \\
57\end{array}$ & $\begin{array}{c}\text { Benzoate } \\
\text { Test } \\
66^{*} \\
94\end{array}$ \\
\hline 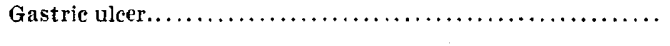 & 1 & . & $\begin{array}{l}68 \dagger \\
96+\end{array}$ \\
\hline 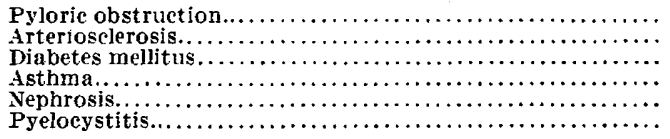 & $\begin{array}{l}1 \\
1 \\
1 \\
1 \\
1 \\
1\end{array}$ & $\begin{array}{l}43 \\
\ddot{62} \\
46 \\
52\end{array}$ & $\begin{array}{l}41 \\
96 \\
99 \\
93 \\
82 \\
71\end{array}$ \\
\hline $\begin{array}{l}\text { * With cardiac decompensation. } \\
+ \text { Benzoate given with the noon meal. } \\
+ \text { Benzoate given } 1 \text { hour before breakfast. }\end{array}$ & & & \\
\hline
\end{tabular}

76 per cent, or the lowest normal figure of 64 per cent. found by Hill ${ }^{20}$ in thirty normal children.

In Table 7 are shown the results of the benzoate test on patients with diseases not renal in nature. Cases of asthma, arteriosclerosis (no clinical signs of kidney involvement), diabetes and gastric ulcer gave normal benzoate test percentages. A benzoate test on a patient with cirrhosis of the liver accompanied by cardiac decompensation gave 66 per cent. A second case of cirrhosis of the liver showed a normal output of hippuric acid in three hours after ingestion of the customary dose of sodium benzoate, as the figure 94 indicates. In neither of these two cases could any free benzoic acid or its salts be found in the urine after the benzoate ingestion.

19. Mosenthal, H. O.: Renal Function as Measured by the Elimination of Fluids, Salt and Nitrogen, and the Specific Gravity of the Urine, Arch. Int. Med. 16:733 (Nov.) 1915.

20. Hill, L. W.: Mild Chronic Nephritis in. Children, J. A. M. A. 75:596 (Aug. 28) 1920. 
Some facts of interest regarding absorption and the possible rôle of this factor in affecting the applicability of the benzoate test are brought out in Cases 12 and 17. In the former, a case of gastric ulcer, a fluoroscopic examination after a barium sulphate meal showed a 10 per cent. retention of this at the end of six hours. Two benzoate tests were made, in each case using one-half the usual dose, the first showing a 96 per cent. elimination in three hours and the second, 68 per cent. In the first case, the benzoate was given one hour before breakfast, but in the second case it was given with the noon meal. Here the difference is clearly attributable to different rates of absorption, this being at a much slower rate while food was in the stomach.

In Case 17, a nearly complete pyloric obstruction was diagnosed from the fluoroscopic examination after a barium sulphate meal. No passage of this material from the stomach into the duodenum during six hours could be observed. The usual dose, $2.4 \mathrm{gm}$. sodium benzoate, was given to this patient immediately after the stomach contents had been removed by means of a stomach tube. The patient was then required to void urine. At the end of three hours, the collected specimen of urine was analyzed and found to contain sufficient hippuric acid to account for an absorption of 41 per cent. of the ingested dose of benzoate. From these findings we conclude that such delay in absorption as might possibly be encountered in applying the benzoate test to cases of suspected nephritis would have no effect on the accuracy of the results if the precaution were taken in all cases of this kind to give the benzoate on an empty stomach, preferably one hour before breakfast.

Case 18 was at first diagnosed as nephritis from the urinary findings, although the blood pressure was normal. Two phenolsulphonephthalein tests on December 19 and 29 showed 35 and 45 per cent. elimination in two hours, respectively. January 6 , blood analysis showed urea nitrogen 12 , creatinin 2 and glucose $111 \mathrm{mg}$, respectively in 100 c.c. blood. January 10, a sodium benzoate test was made and an elimination of 82 per cent. in three hours was noted. This is about 15 per cent. under the normal values which we have found, but not so low as any of the results for nephritics or cardiac decompensation cases. At this time a provisional diagnosis of nephrosis due to the absorption of large amounts of toxic substances from an extensive abscess of the buttocks, involving the sacrum and coccyx, was made. It was thought that the presence of this abscess could account for the urinary findings on which the previous diagnosis of nephritis had been made. Due to the pressure of other duties at this time, unfortunately, no more benzoate tests were made. Subsequent data on this case which terminated fatally are as follows : 
January 28 , the blood urea nitrogen was 43 and the creatinin 4.2 mg., respectively in 100 c.c. blood. February 9, the blood urea nitrogen had risen to 74 and the creatinin to $12.7 \mathrm{mg}$. per 100 c.c. blood. The necropsy diagnoses a few days later were: (1) Acute diffuse glomerular nephritis; (2) streptococcic infection over gluteal and sacral regions.

Case 19 was diagnosed as pyelocystitis, bilateral salpingitis and syphilis. The benzoate test of 71 per cent. indicated lessened functional activity on the part of the kidneys. The phenolsulphonephthalein test was 52 per cent. elimination in two hours.

\section{SUMMARY AND CONCLUSTONS}

1. A modification adapting the Folin-Flanders method for the determination of hippuric acid to albuminous urines is described.

2. Sodium benzoate, in $2.4 \mathrm{gm}$. doses, is completely synthesized into hippuric acid and eliminated as such in individuals whose kidneys have been demonstrated to have been damaged extensively, these findings having in some cases been checked by necropsy findings. In nephritis, hippuric acid is excreted at the same rate whether its source was ingested benzoate or an equivalent amount of hippuric acid in the form of the sodium salt. The synthesis must occur fully as fast as the kidney is able to excrete the hippuric acid formed. Neither benzoic acid itself nor any salt of it has been found in the urine of any patient so far studied after the ingestion of sodium benzoate.

3. The three hour output of hippuric acid on a diet free from fruit and cranberries is relatively too small to affect the results obtained when $2.4 \mathrm{gm}$. sodium benzoate are ingested, and, therefore, has been disregarded in making the benzoate tests. From 95 to 100 per cent. of the $2.4 \mathrm{gm}$. of ingested sodium benzoate appears in the urine as hippuric acid within three hours, and represents the normal average. After ingestion of from 6 to $10 \mathrm{gm}$. sodium benzoate, the rate of elimination is less as shown by Lewis, and Lewis and Karr. ${ }^{21}$ Their findings that after the ingestion of an equivalent amount of hippuric acid the rate of excretion is less than after benzoate ingestion has been confirmed by us. In repeating one of their experiments we obtained a curve of elimination practically identical with theirs.

4. We conclude, that in man the kidney does not play the leading rôle in the synthesis of hippuric acid as has been supposed by various investigators from time to time. It may play a minor rôle, for in the normal individual hippuric acid is excreted at a higher rate after ben-

21. Lewis, H. B., and Karr, W. G.: The Synthesis of Hippuric Acid in the Animal Organism. III. The Excretion of Uric Acid in Man After Ingestion of Sodium Benzoate, J. Biol. Chem. 25:13 (May) 1916. 
zoate ingestion than after hippuric acid ingestion in equivalent amount, and this difference is also noted in some of the cardiac cases, but not in the advanced nephritics.

5. A new renal function test is described in which the ability of the kidney to eliminate hippuric acid at a definite and rapid rate is the criterion. Benzoic acid cannot be substituted for the sodium salt in this test, as shown in Case 27 , Table 4 , for its relatively low solubility in water probably causes a lower rate of absorption. At any rate, after its use the amount of hippuric acid eliminated in three hours is about one-half only of that eliminated in the same time after the ingestion of an equivalent amount of sodium benzoate.

Our thanks are due to Doctors S. Marx White, Moses Barron and M. H. Hoffman of the University Hospital, to Drs. A. Stewart, C. T. Ecklund and L. F. Badger of the Minneapolis General Hospital, to Drs. Rood Taylor and M. D. Ott of the Abbott Hospital and to Dr. M. A. Shillington for their enthusiastic cooperation in carrying out these tests. For helpful discussion of certain pathologic and physiologic aspects of this problem we express our thanks to Drs. E. T. Bell and F. H. Scott of the Departments of Pathology and Physiology of the medical school.

We are indebted to the staffs of the University, Minneapolis General and Abbot Hospitals for the data concerning diagnoses, phenolsulphonephthalein tests and blood analyses. 